FROM MONOLOGUE TO DIALOGUE 
‘To be means to communicate dialogically. When dialogue ends, everything ends.'

M.M. Bakhtin 1984a:252.

Cover illustration: A host reading a request from a listener at the community radio station Pamor in the Parangtritis area south of Yogyakarta, 2002 
V E R H A N D E L I N G E N VAN HET KONINKLIJK INSTITUUT VOOR TAAL-, LAND- EN VOLKENKUNDE

264

EDWIN JURRIËNS

\title{
FROM MONOLOGUE TO DIALOGUE
}

\author{
Radio and reform in Indonesia
}

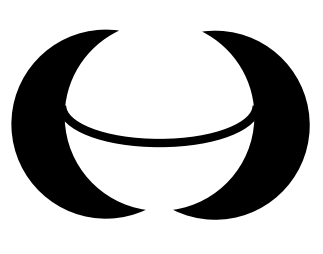

KITLV Press

Leiden

2009 
Published by:

KITLV Press

Koninklijk Instituut voor Taal-, Land- en Volkenkunde

(Royal Netherlands Institute of Southeast Asian and Caribbean Studies)

PO Box 9515

2300 RA Leiden

The Netherlands

website: www.kitlv.nl

e-mail: kitlvpress@kitlv.nl

KITLV is an institute of the Royal Netherlands Academy of Arts and Sciences (KNAW)

Cover: Creja ontwerpen, Leiderdorp

ISBN 9789067183543

(C) 2009 Koninklijk Instituut voor Taal-, Land- en Volkenkunde

No part of this publication may be reproduced or transmitted in any form or by any means, electronic or mechanical, including photocopy, recording, or any information storage and retrieval system, without permission from the copyright owner.

Printed in the Netherlands 


\section{Contents}

I Introduction

Facts and fiction 1

Radio journalism, the public sphere, dialogism 3

Words of gratitude 7

II Reformasi and the medium of radio

Why radio? 9

A short history of Indonesian radio 11

Language and power; New Order's heteroglossia 14

Against monologism; Pasemon and plesetan 17

Reformasi; Carnival and dialogism 20

III Media and publicness

The Depok School and the migration of concepts 25

Habermas, the bourgeois public sphere and the mass media 29

Radio Republik Indonesia; Public radio and the Broadcasting Law 32

Komisi Penyiaran Indonesia; Monitoring the publicness of broadcasting 35

'More than just music'; News radio and segmentation 38

What is new about the news? 43

IV Radio journalism, transition, Indonesianness

The New Order and development journalism 49

Control and contestation 53

KBR 68H and Internews Indonesia; Independent journalism, peace journalism, transparency 57

Indonesia Media Law and Policy Centre; Meta-journalism 65

Friedrich Naumann Stiftung; Contests, inserts and virtual interactivity 68 
$\mathrm{V}$ The actors of interactive radio journalism

The genre of the audience participation programme 79

Hosts addressing their audiences 81

The authority of experts 89

Editors and gatekeepers 92

VI The activity of interactive radio journalism

Multi-sided journalism 98

'News-interaktif-solutif'; From practical solutions to sustainable development 102

'Wandering around the city'; Virtual travel and regional awareness 106

Talk-back radio and the refeudalization of the public sphere? 114

Media literacy 118

VII The discipline of talking

The media of the Bali Post Group 121

Global FM; 'Don't be unwilling to talk' 124

The discipline of talking; 'Global terkini' and 'Jumpa pendengar' 126

Contests for listeners; Awarding 'Social empowerment personalities' 132

VIII Radio komunitas and the imagination of community

Accessibility, participation, self-awareness 142

Aura and the everyday 144

Community radio in Central Java 146

Campus radio in Yogyakarta 149

Grassroots theatre, Brecht; Umfunktionierung and Verfremdung 153

Nostalgia for aura 156

IX Conclusion; Reformasi and the dialogical public sphere

List of abbreviations

Bibliography

Index 